$12-31-2018$

\title{
The impact of micro-scale solar power supply for rural households, in Central Kalimantan Province, Indonesia
}

\author{
Lilis Heri Ms Cicih \\ Universitas Indonesia, lilisherimc@gmail.com \\ Endih Herawandih \\ BEEworld and IPB
}

Follow this and additional works at: https://scholarhub.ui.ac.id/ajce

Part of the Social and Behavioral Sciences Commons

\section{Recommended Citation}

Ms Cicih, Lilis Heri and Herawandih, Endih (2018). The impact of micro-scale solar power supply for rural households, in Central Kalimantan Province, Indonesia. ASEAN Journal of Community Engagement, 2(2). Available at: https://doi.org/10.7454/ajce.v2i2.134

Creative Commons License

(c) (i) ()

This work is licensed under a Creative Commons Attribution-Share Alike 4.0 License.

This Research Article is brought to you for free and open access by the Universitas Indonesia at ASEAN Journal of Community Engagement. It has been accepted for inclusion in ASEAN Journal of Community Engagement. 


\title{
The Impact of Micro-Scale Solar Power Supply for Rural
}

\section{Households, in Central Kalimantan Province, Indonesia}

\author{
Lilis Heri Ms Ciciha*, Endih Herawandih ${ }^{\mathrm{b}}$ \\ ${ }^{a}$ Universitas Indonesia

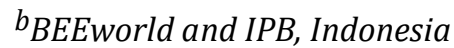 \\ Received: October 8 ${ }^{\text {th }}, 2018$ || Revised: December $4^{\text {th }}$ and 13th || Accepted: December 30 $30^{\text {th }}, 2018$
}

\begin{abstract}
Electricity is one of the basic necessities of people. The provision of micro-scale solar electricity in remote areas is needed to increase public access to electricity as a way of improving the capacity of household members. The aim of this community engagement program is to increase the electricity access of agricultural households as a means of providing financial, economic, and sociocultural benefits to farmer communities. Theoretical background. Based on the theoretical concepts (Zhu, 2011), the community engagement must be tailored to the population interest and community-based organizations must be involved in any engagement initiative. There are six major components of a community engagement, which are collaboration, accessibility, accountability, education, principles, and organizational capacity. Methods. This program was carried out in the Central Kalimantan village of Kampung Baru in Katingan Kuala, Katingan, which was chosen based on its potential to be developed as a food-crop producing region amidst its adverse characteristics (no electricity, a remote area, no land vehicles, and a population living in poverty). The community engagement activities conducted under this program covered observations, village-consultation approaches, participatory education, participatory rural appraisal, and interviews. Transfer of knowledge to mobilize and organize the community was carried out through adult education, learning through a hands-on approach, and on-site training. The beneficiaries were selected from poor families adjudged in part based on the poor condition or habitability of the house and with school-age children in the household. Results and discussion. Around $96 \%$ of rural households were found to have food-crop farming livelihoods with only $29 \%$ of them having another business. This program' selected 43 households (HHs) and two Muslim praying rooms. Based on the beneficiaries' survey responses, $98 \%$ were "very happy" while $2 \%$ were "quite happy" with this program. A total of $86 \%$ of households could expand their respective businesses. The average financial benefits amounted to an estimated 2.72 million rupiah per month, and the socio-cultural benefits impacted $96 \%$ of the children in the form of increased diligence to learn owing to having acquired greater free time at night. Conclusion. The empowerment program in the form of the provision of micro-scale solar electricity lighting resulted in positive socio-economic impact on the beneficiaries due to savings in electricity costs that even led to additional businesses for some of the beneficiaries, and children's increased diligence in learning especially at the night.
\end{abstract}

Keywords: micro-scale electricity; solar power; benefit and impact; poverty; community engagement

\section{Introduction}

Poverty in all its forms is an enormous challenge for national development. Eradicating poverty tops the list of Sustainable Development Goals. This involves targeting the most

*Correspondence Author: lilisherimc@gmail.com 
vulnerable, increasing access to basic resources and services, and supporting communities (UNDP, 2018). In Indonesia, in 2017 there were still 10.6\% of population living below the national poverty line (The World Bank, 2018). Therefore, the country needs a strong strategy to alleviate poverty, and this need not only come from government programs but also through non-governmental endeavors, such as community engagement.

Community engagement programs can serve as a very important tool for fostering capacity-building and forming independent communities in the goals of development and policy implementation (Aggarwal, 2014). Capacity building and education for business are important strategies for promoting development in rural areas (Lopez, 2015).

There are opportunities as well as challenges in community engagement. Opportunities can include the education of residents, surfacing of new ideas, and gaining buy-in early on. Challenges can include the dearth of advice or knowledge on how to engage with low-income community members and the difficulty of defining the concept of "community representative" (Wysen, 2014). Building a society requires broad efforts covering the construction of facilities and infrastructure and changing people's behavior, which is an undertaking that entails perseverance and patience.

Poor communities in rural areas generally face problems related to limited access and knowledge on several matters. This often leads to the resident's low capacity. For example, rural households in remote areas face limited access to full-day availability of electricity, which then leads to non-optimal children's learning and poor operations of household businesses. Residents also tend to have limited knowledge and be poorly motivated such that they need to be supported to be able to innovate.

Therefore, there is a need for a program to provide society services that would help increase its levels of capacity and community empowerment. Such service provisions can include the application of science and technology for electricity generation. This engagement program is very important for the rural community as evidenced by studies showing that electrification significantly raises female employment within five years by releasing women from home production and enabling microenterprises (Dinkelman, 2011). Electricity provision also positively impacts people's lives in other ways, such as by improving the economic condition of the community or nation (Nugraha, 2013; Dennis, 2015). In addition, rural electrification programs can reach more poor households and 
more greatly impact rural folks' lives by creating new opportunities for, and enhancing the synergies between, agricultural and non-agricultural sectors (Torero, 2015). It has also been demonstrated that the presence of electric lighting, in general, can improve security, leading to a general feeling of guaranteed safety (Dulinger, 2010). These effects will enhance the confidence of the community, that in turn will, in the long run, pave the way for fostering and developing existing talents for innovation and entrepreneurship (Dulinger, 2010; Kumara, 2010; Timilsina, 2011).

The Indonesian government has issued a National Energy Policy by creating a road map covering the period until 2050 (DEN, 2014). This policy is intended as a guideline for directing energy management toward the realization of energy independence and security to support national development. In addition, this policy regulates the issue of energy availability by increasing exploration of resources, potential and proven reserves of energy from both fossil and new and renewable energy.

One example of renewable energy is electricity generated by solar power plants (Kumara, 2010). Solar energy refers to sources of energy that directly come from the light or heat of the sun (Bradford, 2006). In Indonesia, the energy potential of solar electricity amounts to around $4.5 \mathrm{~kW} / \mathrm{m} 2 /$ day (Rif'an, 2012). Such solar electricity volumes should allow the government to supply electrical energy to remote areas that have not yet been powered by electricity. A research study has shown that the use of the Solar Home System (SHS) is very useful for communities during the night, especially benefiting students and mothers who have small children, as well as generally helping the residents of Cegi village who have previously relied on oil lamps for their lighting (Nugraha, 2013).

Amidst these conditions, we conducted a community engagement program in Kampung Baru Village in Central Kalimantan by providing micro-scale electricity lighting facilities. This program is an activity of community involvement from initial planning to the installation of electrical facilities. This program aimed to increase the electricity access of agricultural households as a way of providing financial, economic, and sociocultural benefits to farmer communities, and thus differs from the research at Karang Asem, Bali (Nugraha, 2013) that was conducted to determine the socioeconomic impacts of communities that had already installed SHS.

The Kampung Baru village that is the subject of the present community engagement program is in a remote part of Kalimantan. It is difficult to reach the village, being 
inaccessible by land vehicles; to get there, one needs to take an eight-hour trip by boat from the capital district. In this village, most people live in poverty and had no electricity. This community engagement program aimed to determine the socioeconomic benefit that could be derived from, and the socio-cultural impact of, providing micro-scale solar power supply to rural households. Under this program, we additionally conducted capacity-building activities in the effort to improve the capacity of individuals and households. We hoped to develop and increase the motivation, awareness, and creativity of the community, and especially, the youth toward the utilization of potential local resources for alternative business endeavors to increase household income.

This program entailed the collaboration between institutions of higher education and their larger communities for mutually beneficial exchanges (Weerts, 2010) because it requires strong capacity building, fostering institutional capacity, and enhancing coordination (The World Bank, 2017).

This program was selected based on the assessment that the rural community of the village of Kampung Baru was in dire need of what this program can provide, which was all-day electrification that they have always lacked. There is little empirical evidence to underpin strategies of poverty reduction through income generation in small scale rural enterprises through supplying energy (Dijk, 2010). Nonetheless, this program sought to add to the literature showing that electrification contributes to poverty reduction. This community engagement program envisions the households of the target agricultural village as receiving financial, economic, and socio-cultural benefits from solar energy provision by way of increasing their income through the increased ability to develop alternative livelihood enterprises if electricity supply is continuous and stable. In addition, these households could save considerable amounts of money with lower lightning costs.

\section{Methods}

This program was started in Kampung Baru village, Katingan Kuala subdistrict, Katingan district, in Central Kalimantan in 2015. This village was purposively selected based on the criteria: remote location with no land vehicles; residents' state of poverty; lack of continuous electricity; and its potential to be developed as a food-crop producing area. 
The unit of analysis for the provision of micro-scale electricity lighting facilities is the household. Participant beneficiaries were consciously selected based on the following criteria: poverty, poor habitability of the house, and presence of school-age children.

Based on the 2015 Katingan Kuala data, the number of households (HHs) in Kampung Baru Village is 408. From this data, we calculated the ideal number of household beneficiaries by using the online Survey System package. Using the confidence level of $95 \%$ and confidence interval of $15 \%$, we decided on $39 \mathrm{HHs}$ as the total number of household beneficiaries.

The activities in the community engagement program were carried out through two steps, namely 1) community preparation activity and needs assessment and 2) community engagement and knowledge transfer. In the first step, community preparation activities were carried out through village-consultation approaches and participatory education. Needs assessment was carried out by observation, interviews, and Participatory Rapid Appraisal (PRA). The PRA method is an interactive data collection process conducted at a community level or with a specific community group of interest. This method is applied at the design, early implementation, and evaluation phases of a project cycle (Coghlan, 2014). For interviews, we used semi-structured questionnaires as research instruments.

The second step, community engagement and knowledge transfer, involved the provision of micro-scale electricity lighting facilities to each of the household beneficiaries. We also conducted transfer of knowledge to mobilize and organize the community through adult education, hands-on-learning, and on-site training.

We analyzed the cost of this program's benefits to the households. An indicator of the real benefits is the financial benefits that can be used to measure economic benefits. Financial benefits were calculated based on the amount of costs incurred by each household prior to and after the implementation of the community engagement program, with the costs incurred by each household for direct home lighting being the main variable in the calculations. The calculation of financial benefits, to determine the real benefits obtained by the target community from the implementation of the program, was made only after comparison of the before- and after- the implementation of the program. The average cost incurred before the program was the sole parameter utilized for financial benefit calculations. The Benefit (B) / Cost (C) ratio was calculated by comparing 
the net financial benefits for 10 years with the investment costs incurred for community empowerment program. The assumption used in this calculation is that the costs of implementing the community empowerment program are considered as investment costs that are only intended to provide solar electricity. The 10-year calculation was considered achievable because the theoretical technical life of solar panels as the core of solar power plants is 15 years; hence, the assumption of a 10 -year program period is realistic.

The expected outcomes of the community engagement program are: 1) micro-scale electricity installations, as available household beneficiaries; 2 ) increased motivation and awareness; and 3) increased creativity of the community, especially its young members, in the utilization of potential local resources.

\section{Result and Discussion}

\subsection{Location of Community Engagement}

Kampung Baru is one of the villages in Katingan Kuala district, Katingan regency, Central Kalimantan (See Figure 1 for its location). Based on rapid needs assessment, this location has the potential natural resources for food-crop production. Related to this, the specific characteristics of this village include:

a. Potential production output is quite large but the productivity per unit is still low and needs to increase;

b. Available capital resource supply is lacking so farmers are less equipped to improve their cultivation techniques to boost productivity;

c. Farmers' land ownership is generally quite extensive (1.75 ha) but not all farmers enjoy decent benefits due to low productivity ( 2.5 to 5 tons per ha), which becomes an even more serious problem in case of crop failure;

d. It enjoys the economic potential of forest resources, which are yet to be exploited through a creative economic effort to improve alternative livelihoods; and

e. Partner potential and community motivation could impact program sustainability. 

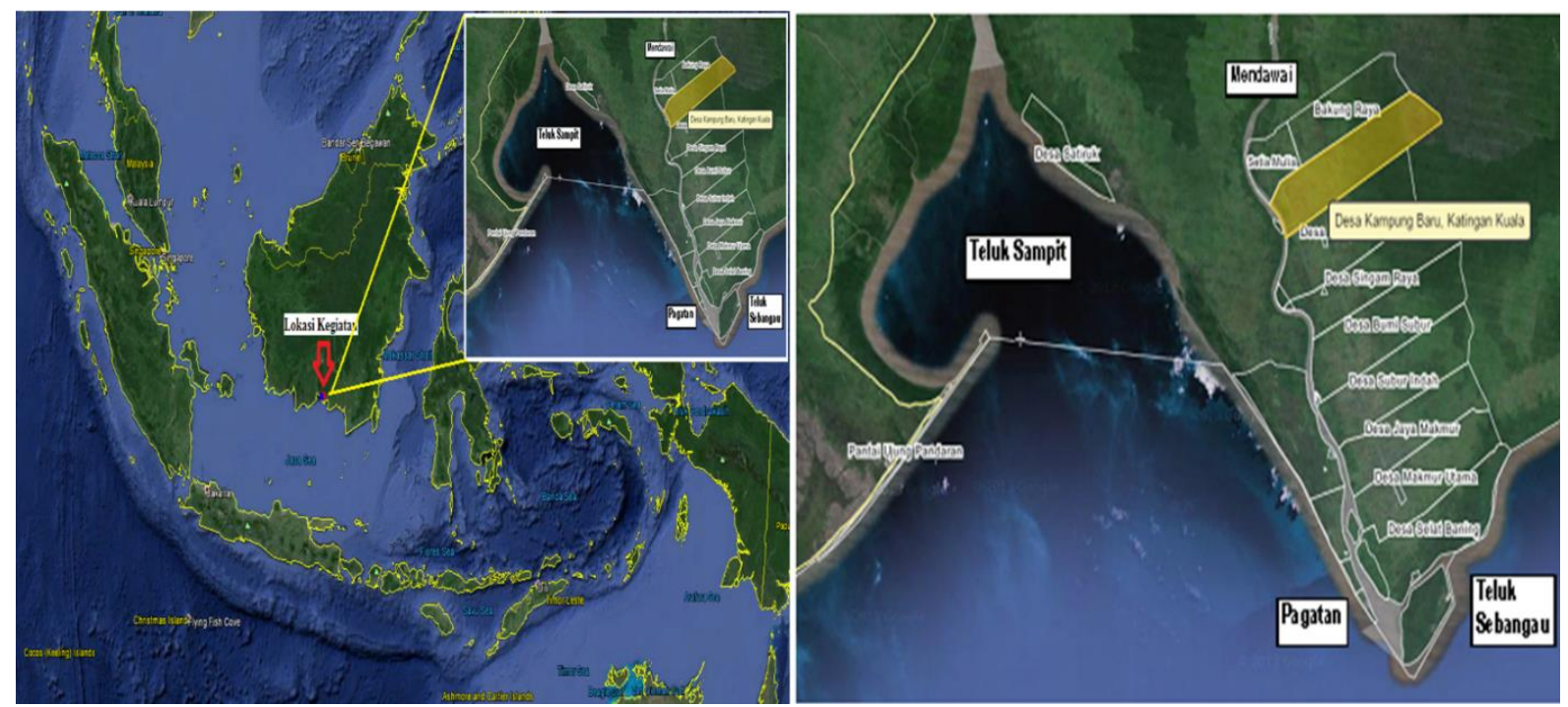

Fig. 1 Location of Kampung Baru Village, Katingan Kuala, Katingan, Central Kalimantan, 2015

Source: Google map (2018)

\subsection{Household Beneficiaries Characteristics}

Beneficiary households based on the sample calculation numbered 39 HHs. At the time of initial socialization and inventory, the number of beneficiaries was as many as 45 households that included two Muslim praying rooms. The beneficiaries were also selected based on other household indicators, such as the presence of school-age children. Combining these verification activities with the results of our agreement with the local community leaders, the program came up with 45 beneficiaries: $43 \mathrm{HHs}$ and two Muslim praying rooms. Examples of these activities include the process of socialization, discussion, and coordination with the local community of Kampung Baru village (see Fig. 2). They were mostly conducted several times during the day and at night (the villagers who mostly worked in the farming sector were unavailable during the day). 
Lilis Heri Ms Cicih, Endih Herawandih | ASEAN Journal of Community Engagement | Volume 2, Number 2, 2018

a

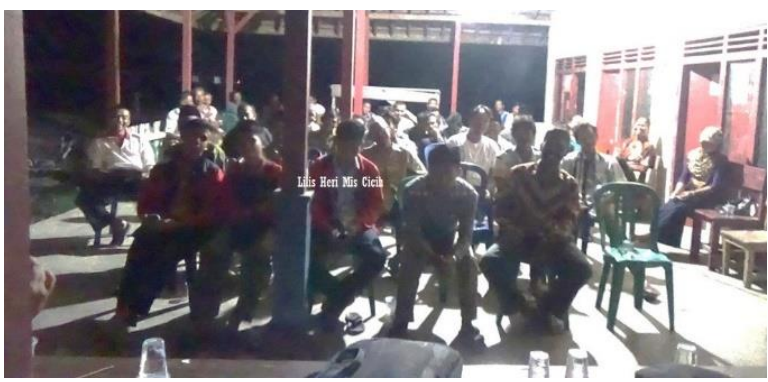

b

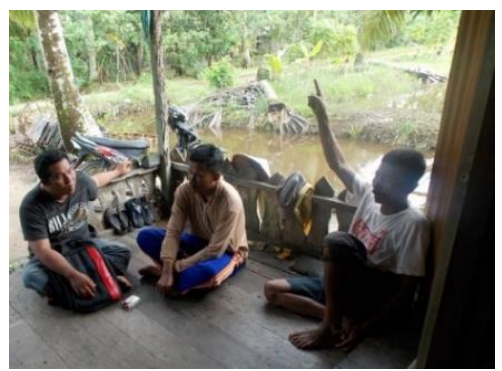

c

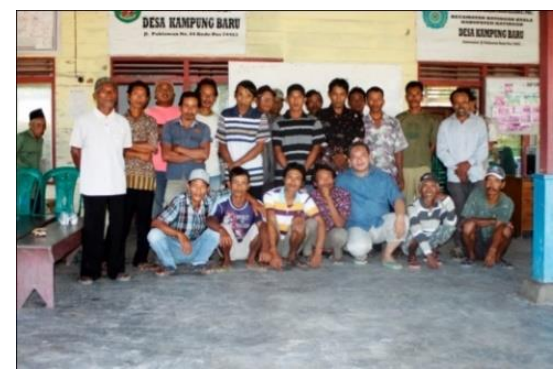

Fig. 2 (a) Meeting with local participants; (b) Socialization program for the rural community; (c) after meeting and discussion

Source: Community Engagement Team (2015)

Table 1 presents the characteristics of household heads, with the average age being 40 years, even though some are much older. In general, they have had seven years of schooling, which means that they have completed elementary schooling. Although not all are natives, they have lived in the village for 25 years on an average. Fertility of the $\mathrm{HH}$ heads is quite high, having two children on an average.

Table 1. Characteristics of Household Head of Beneficiaries, Kampung Baru, 2015

\begin{tabular}{lccccc}
\hline \multicolumn{1}{c}{ Parameters } & Minimum & Maximum & Means & Median & $\mathrm{N}$ \\
\hline Age (years) & 28 & 61 & 42 & 40 & 45 \\
\hline Years of Schooling & - & 12 & 7 & 6 & 45 \\
\hline Number of Children & 1 & 6 & 3 & 2 & 45 \\
\hline $\begin{array}{l}\text { Length of stay in the village (in } \\
\text { years) }\end{array}$ & 3 & 33 & 25 & 28 & 45 \\
\hline
\end{tabular}

Almost all beneficiary HHs are engaged in work or some type of agricultural work with as many as $96 \%$ being engaged in crop farming livelihoods. This means that $4 \%$ of the residents of this village had their main jobs outside agriculture: working as construction workers, teachers or village officials. Only $29 \%$ of beneficiary HHs have another business undertaking, the most common type being brick processing, tofu processing, and trade.

In Kampung Baru village, possession of large numbers of buffaloes and/or having swallow nests are considered poverty indicators. Raskin (subsidized rice) for the poor was not used as the main indicator because all the households received it.

\subsection{Benefits and Cost of the Micro-scale Electricity Installations}


This community empowerment program providing micro-scale solar power plants reached $100 \%$ of its targets. Thus, the total number of beneficiaries was 45 i.e., 43 HHs and two Muslim praying rooms. All the necessary equipment was successfully installed and handed over to the beneficiary HHs. Before the program's provision of micro-scale solar power plants, as many as $63 \%$ of the households used electricity from government (installed from their neighbor/not own property). Moreover, 33\% of the households used kerosene lamp while 4\% used private generators. Figure 3 shows a beneficiary's house before installation (a) and after the installation of a micro-scale solar power plant (c). Figure (b) shows one of these micro-scale solar power packages consisting of the following: a solar cell (20 watts, 12 volts, 2 amperes), 4 LED DC lights (12 volts 5 watts or 4 watts), a solar charge regulator, cables, and a switch tool.

a

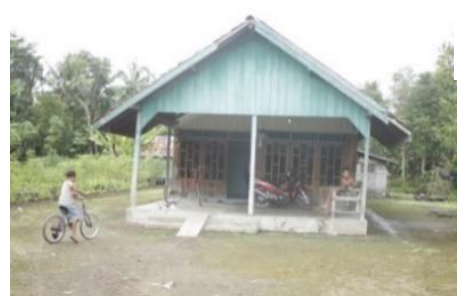

b

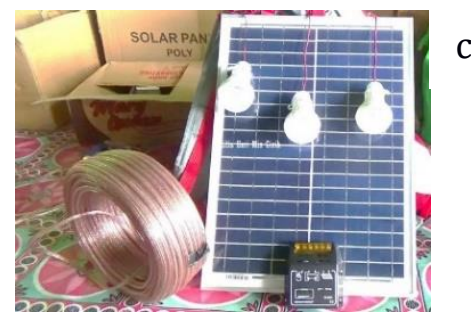

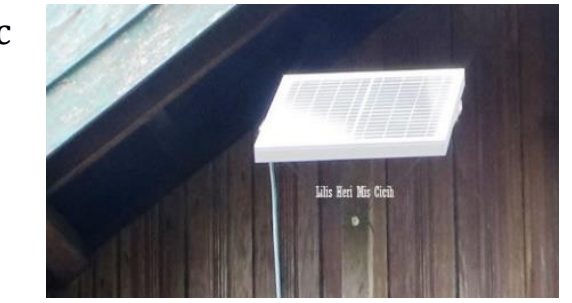

Fig. 3 (a) before installation; (b) micro-scale solar power package; (c) after installation Source: Community Engagement Team (2015)

As an indicator of beneficiaries' satisfaction, almost all target beneficiaries (98\%) gave the answer "very happy" and only $2 \%$ said they were "quite happy." This program also benefited $86 \%$ of households who engage in non-farming activities as income source, such as tofu processing, bricks, and selling/trade. Figure 4 shows some household beneficiaries who received micro-scale solar power. Figure 4(a) displays a discussion and evaluation activity about the benefits and impacts of micro-scale solar power installation.
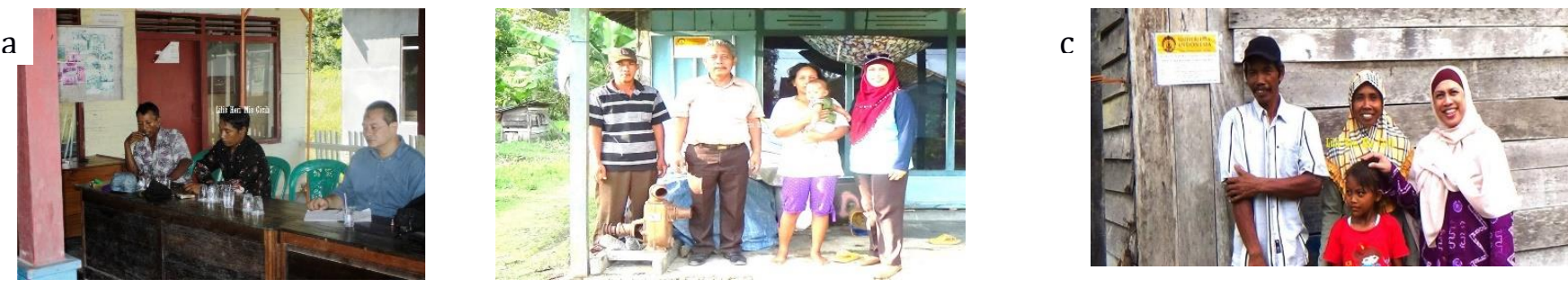

Fig. 4 (a) meeting with household beneficiaries; (b) observation and interview of household beneficiaries; (c) observation and interview of household beneficiaries Source: Community Engagement Team (2015) 
Two kinds of benefits were received by the beneficiary households, namely social and economic benefits. One benefit is the ability to work at night without the additional operating costs normally required to increase productivity and business efficiency. Another benefit is the reduced dependence on government electricity usually obtained from neighbors. One other benefit is sustained work or business productivity even after the government-provided electricity has run out. A point worth mentioning is that another study in Karang Asem Bali showed that social and economic benefits were derived from SHS (Nugraha, 2013), somewhat like the studies of Timilsina (2011), Torero (2015), and The World Bank (2017).

Analysis of economic benefits and costs entailed inspecting the daily costs incurred for household lighting prior to the implementation of the program, sorted according to the energy source. Table 2 shows that the lowest average cost was incurred by households that utilized government electricity while the highest cost was incurred by households that used private generators. The cost of using lamps powered by kerosene was higher than that of government-supplied electricity but lower compared to the use of private generators.

Table 2. Household lighting costs by different energy sources, Kampung Baru village, 2015

\begin{tabular}{llcc}
\hline \multirow{2}{*}{ Resource } & \multicolumn{3}{c}{ Cost per Month (Rupiah) } \\
\cline { 2 - 4 } & Min & Max & Average \\
\hline Government electricity (installed from & 15,000 & 50,000 & 43,333 \\
their neighbor/not own property) & 30,000 & 300,000 & 86,250 \\
Kerosene lamp & 300,000 & 300,000 & 300,000 \\
\hline Private generator &
\end{tabular}

The financial benefits derived from this calculation were the real financial benefits obtained by beneficiary HHs after receiving a micro-scale solar electricity package for lighting purposes. The assumed cost refers to the direct cost for the government-supplied electricity, kerosene lamps or generators. Thus, other costs that were incurred were not considered.

Likewise, the financial benefits calculated in this study did not consider operational and maintenance costs, so they had to be balanced with the costs of using energy sources 
Lilis Heri Ms Cicih, Endih Herawandih | ASEAN Journal of Community Engagement | Volume 2, Number 2, 2018

other than solar energy. The parameters of the average cost incurred by each beneficiary household were calculated and the financial benefits are shown in the following Table 3.

Table 3. Costs incurred for energy sources by households, Kampung Baru Village, 2015

\begin{tabular}{lcccc}
\hline \multirow{2}{*}{ Resource } & \multicolumn{4}{c}{ Benefit Cost per Month (Rupiah) } \\
\cline { 2 - 5 } & 1 day & 1 month & 1 year & 10 years \\
\hline Government electricity (installed from & & & & \\
their neighbor/not own property) & 35,556 & $1,066,667$ & $12,800,000$ & $128,000,000$ \\
Kerosene Lamp & 38,333 & $1,150,000$ & $13,800,000$ & $138,000,000$ \\
\hline Private generator & 16,667 & 500,000 & $6,000,000$ & $60,000,000$ \\
\hline Total of Financial Benefits & $\mathbf{9 0 , 5 5 6}$ & $\mathbf{2 , 7 1 6 , 6 6 7}$ & $\mathbf{3 2 , 6 0 0 , 0 0 0}$ & $\mathbf{3 2 6 , 0 0 0 , 0 0 0}$ \\
\hline
\end{tabular}

Source: Community Engagement Team (2015)

The value of benefits that the beneficiary households will reap in 10 years will amount to 326 million rupiah. When compared with the costs to be incurred under the community empowerment (micro solar electrification) program, the net benefits (B/C ratio) for 10 years is 3.26. With a $\mathrm{B} / \mathrm{C}$ ratio of that size, the implementation of the community empowerment program in the village of Kampung Baru by the University of Indonesia team can be considered financially beneficial.

Apart from its direct financial benefits to the households, the children also benefited. They believe that the micro-scale electricity lighting helps in their education. As many as $100 \%$ of beneficiaries regard the provision of micro-scale electrical lighting as useful. It was found that $96 \%$ of children have shown increased diligence toward studies because the lighting program resulted in their having freer time at night. Only $4 \%$ of the beneficiaries' children said they have not experienced changes relating to learning in their homes.

On the question of the utilization of solar power plants for use other than lighting, as many as $25 \%$ of the beneficiaries of micro-scale solar power plants expressed awareness of the benefits or uses of the lighting packages other than for lighting, such as for cellphone chargers and battery chargers.

Based on the discussion of the program benefits and on interviews with the beneficiaries, we think it is necessary to manage micro solar electric lighting. All the beneficiaries believe that it is necessary to establish a management entity or institution for this purpose, and as many as $96 \%$ of beneficiaries expressed their willingness to form a management institution. In addition, all beneficiaries expressed their willingness to 
maintain and manage micro solar electric lighting. Likewise, $96 \%$ of beneficiaries were willing to pay for routine maintenance and management costs, which by itself is an indicator of the serious desire of the beneficiaries to keep the entire package of microscale solar power plants operational for as long as possible. The amount of rupiah that the households are willing to part with to pay routine fees for a management group are as follows:
a. Lowest value: $\operatorname{Rp~5,000/month~}$
b. Highest value: Rp 50,000/month
c. Middle Value: Rp 5,000/month
d. Average Value: Rp 8,824/month

\subsection{Impact of the Program for Beneficiaries}

Solar power plants on a micro-scale are the only power plants that cause the least biological, physical, and chemical impacts on the environment. Because of the clean process of energy generation from solar energy, it could be claimed that solar power plants only negatively impact the environment during its end-stage/recycling phase after they have outlived their usefulness and have become scrap. However, because of the minuscule scale of this type of solar energy plants, their only environmentally risky component is the battery. Nonetheless, the battery can be recycled if it becomes outdated. The solar panels themselves only produce low negative impact, especially given that it can last up to 15 years. Thus, solar power plants do not cause environmental pollution, not even greenhouse gases, although it can still have some indirect impact on the environment.

Solar panel technology has been advancing to produce cheaper and more efficient units. Recent developments have led to the increasingly thinning dimensions of solar panels without losing their efficiency to capture natural and clean energy. Japan is notable for its innovations in solar panel technology that it began around 50 years ago. Japanese research and development experts continue to prioritize solar panel development in order to meet clean and environmentally friendly electricity needs.

Looking further into solar energy technology and utilization, it can be noted that the use of solar panels practically negates any negative impact that they cause. Because of their low negative impact, solar panels were chosen to build a sustainable and low impact 
Lilis Heri Ms Cicih, Endih Herawandih | ASEAN Journal of Community Engagement | Volume 2, Number 2, 2018

energy supply system under this program. The impact of micro-scale solar power plants in Kampung Baru village is described in Table 4 below, showing that the highest impact of micro-scale solar power plants is on the finances of the households while its greatest social impact is on the children's length of nighttime study time.

Table 4. Impact of micro solar electric lighting, Kampung Baru Village, 2015

\begin{tabular}{llc}
\hline \multicolumn{1}{c}{ XParameter } & \multicolumn{1}{c}{ Impact } & Value \\
\hline Micro-scale economic factors & \multicolumn{1}{c}{} \\
\hline Financial benefit & Reduced household expenses & +++ \\
\hline & Increased opportunities to start businesses & ++++ \\
\hline Consumption and income per capita & Fostering the culture of saving & ++++ \\
\hline Socio-cultural patterns & & + \\
\hline Way of life & Increased demand for solar power plants & \\
\hline & Increase in the length of study time during & \\
\hline & the night & ++ \\
\hline Socio-cultural patterns & Changes in social activities & ++ \\
\hline & Increased activities at night & ++ \\
\hline
\end{tabular}

Source: Community Engagement Team (2015)

Note: *** strongly agree; $\quad$ ** agree; * disagree

\section{Conclusion}

The community engagement program entitled Micro-Scale Solar Power Supply for Rural Households in Kampung Baru Village has reached its target (45) beneficiaries of 43 HHs and two Muslim praying rooms.

This program has provided financial and social benefits to the rural HHs in the target village. Almost of all beneficiaries consider themselves to have been helped by the existence of this micro-scale solar electricity program because their children could study longer than usual. In addition, the diligence level of $96 \%$ of the children from the beneficiary households increased. The beneficiaries have also expressed pleasure in the fact that the installation of the solar power plants could reduce their dependence on the government-supplied electricity and kerosene while improving or increasing their opportunity to engage in an alternative business undertaking.

Future community engagement programs could utilize improved or more efficient electrical power source or units to better serve many purposes. The steps taken in this 
community engagement program could be improved, and the participatory action research can be applied to empower the local youths to be able to manage how to set up SHSs.

\section{Acknowledgements}

This community engagement program was funded by the 2015 Community Engagement grant of Directorate of Research and Community Service of Universitas Indonesia. We would like to extend our gratitude to Directorate Research and Community Engagement Universitas Indonesia for its kind support of the community engagement program.

\section{References}

Abdulkadir, A. (2011). Environmentally Friendly Power Plant Technology. Volume Electricity Series, 1. Bandung: ITB.

Aggarwal, V., \& Alison, F., Hana, S. F., \& Huang, \& CC., Li. S., \& Moilanen, S., \& Onda, C., Ratledge, N., \& Speirs, S., \& Wong, J. (2014). Rural Energy Alternatives in India: Opportunities in Financing and Community Engagement for Renewable Energy Micro grid Projects. Retrieved September 27, 2018, from https://wws.princeton.edu/sites/default/files/ content/591f\%20Rural\%20Energy\%20Alternatives\%20in\%20India.pdf.

Alvial-Palavicino, C., \& Natalia, G., \& Guillermo, J., \& Lorenzo R., \& Rodrigo P. (2011). A methodology for community engagement in the introduction of renewable based smart microgrid. Energy for Sustainable Development, 15(3), 314-323.

BPS-Statistics. (2015). 2015 Katingan Kuala in Figures. Retrieved December 7, 2018, from https://katingankab.bps.go.id/publication/download.html.

Coghlan, D., and Brydon-Miller, M. (2014). Participatory Rapid Appraisal. The SAGE Encyclopedia of Action Research. Retrieved December 7, 2018, from http://methods.sagepub.com/reference/encyclopedia-of-actionresearch/n244.xxml.

Dennis, K. (2015). Environmentally Beneficial Electrification: Electricity as the End-Use Option. The Electricity Journal, 28 (9), 100-112. 
Dewan Energi Nasional (DEN) Republik Indonesia or National energy Council, Republic of Indonesia. (2014). National Energy Policy, Road Map for Energy Resilience and Independence. Retrieved December 5, 2018, from https://den.go.id/index.php/ dinamispage/index/471-.html.

Dijk, A. L.K., \& Joy, C. (2010). Impacts of Electricity Access to Rural Enterprises in Bolivia, Tanzania and Vietnam. Energy for Sustainable Development, 14(1), 14-21.

Dinkelman, T. (2011). The Effects of Rural Electrification on Employment: New Evidence from South Africa. American Economic Review, 101(7), 3078-3108.

Dulinger, B., Reinders, A., Toxopeus, M. (2010). Enviromental Benefits of PV Powered Lighting Products for Rural Area in South East Asia: A Life Cycle Analysis with Geographic Allocation. Netherlands: Dept. of Design, Production \& Manage., Univ. of Twente, Enschede.

Khandker, S. R., \& Hussain A. S., \& Rubaba, A., \& Douglas F. B. (2012). Who Benefits Most from Rural Electrification? Evidence in India. Retrieved September 26, 2018, from https://ageconsearch.umn.edu/bitstream/125090/2/AliR.pdf.

Kumara, N.S. (2010). Solar Cell Power of Urban Household Scale and Its Availability in Indonesia. Technology Electro, 9(1), 68-75. Retrieved December 4, 2018, from https://www.researchgate.net/publication/312498193.

Lopeza, M., \& Raquel, P. (2015). Development in rural areas through capacity building and education for business. Procedia - Social and Behavioral Sciences, 197, 18821888.

Mendes, P. P. (2009). Teaching Community Development to Social Work Students: A Critical Reflection. Community Development Journal, 44(2): 248-262.

Narayanasamy, N (2009). Participatory Rural Appraisal: Principles, Methods and Application. Los Angeles: Sage Publications.

Nugraha, I. M. A., Giriantari, I.A.D., and Kumara N.S. (2013). Proceeding Conference on Smart-Green Technology in Electrical and Information Systems Bali, 14-15 November 2013. Retrieved December 4, 2018 from https://www.researchgate.net/publication.

Rif'an, M., Pramono, S.H., Shidiq, M., Yuwono, R., Suyono, H., Suhartati, F. (2012). Optimization of Utilization of Solar Power in the Electrical Engineering Department, Universitas Brawijaya. EECCIS Journal, 6(1): 44-48. 
Tan, A. (2009). Community Development Theory and Practice: Bridging the Divide between 'Micro' and 'Macro' Levels of Social Work. Presented at NACSW Convention, Indianapolis, IN.

The World Bank. (2017). Switching on Remote Communities through Electricity Access in Mexico. Retrieved September 26, 2018, from https://www.worldbank.org/en /results/ 2017/11/01/switching-on-remote-communities-through-electricityaccess-in-mexico.

The World Bank. (2018). Basic 2018 Statistics. Retrieved December 6, 2018, from https://www.adb.org/sites/default/files/publication/419891/basic-statistics2018.pdf.

Timilsina, G. R., Kurdgelashvili, L., Narbel, P. A. (2011). A Review of Solar Energy: Market, Economics and Policies. The World Bank Development Research Group Environment and Energy Team.

Torero, M. 2015. The Impact of Rural Electrification: Challenges and Ways Forward. Revue d'économie du Développemen Journal, 3(23), 55-83.

UNDP. (2018). Goal 1: No Poverty. Retrieved December 6, 2018, from http://www.undp.org/content/undp/en/home/sustainable-developmentgoals/goal-1-no-poverty.html.

Weerts, D. J., \& Lorilee R. S. (2010). Community Engagement and Boundary-Spanning Roles at Research Universities. The Journal of Higher Education, 81(6), 632-657.

Wysen, T. (2014). 5 Opportunities (and Challenges) of Community Engagement. Retrieved September 26, 2018, from https://www.livingcities.org/blog/653-5opportunities-and-challenges-of-community-engagement.

Zhu, C. (2011). Community Engagement: A summary of theoretical concepts. Calgary Alberta: Public Health Innovations and Decision Support Alberta Health Services. $\begin{array}{llll}\text { Retrieved } & \text { September } & \text { 26, 2018, from }\end{array}$ https://www.albertahealthservices.ca/poph/hi-poph-surv-comm-phids-engageconcepts.pdf. 